\title{
Assessment of the caries risk and the cooperativity of 5-7-year-old children from Varna
}

\author{
Evgeni Dimitrov, Milena Georgieva-Dimitrova
}

\author{
Department of Pediatric Dentistry, Faculty of Dental \\ Medicine, Medical University of Varna;
}

\begin{abstract}
Introduction: For the caries management of the carious process it is necessary a complex approach, which includes caries risk assessment, recommendations for healthy behavior and clinical professional care from the general dental practitioners. The cooperativity of the most of the little patients can not provide the necessary conditions for treatment and restoration of the affected hard tooth tissues.
\end{abstract}

Aim: Assessment of the caries risk and the cooperativeness of 5-7-year-old children.

Materials and methods: Clinical examination includes 100 children on 5-7 years of age from Varna, whose cooperativity is assessed by the dentist using the 4-grade scale of Frankel and data received from interviewed parents. The caries risk assessment is done by tool of American Academy of Pediatric Dentistry (AAPD).

Results: The children's behavior is slightly negative at $32 \%$ of the children, at $44 \%$ it is positive and strongly positive behavior have $24 \%$. There is no statistically significant difference in the received results for the three groups of children $(p>0,05)$. The parents assess their child as negative before the dental treatment in $35 \%$ of the cases and as positive in $47 \%$. The parents assess the behavior for $18 \%$ of the children as strongly positive. Doing the caries risk assessment the most significant factors are the clinical data $\operatorname{dmf}(T+t)$ and the caries activity. Regarding the oral hygiene and low social status respectively 58\% and 59\% of the children are classified in the group of medium risk. Regarding the risk biologic factors such as carbohydrate intake and caries activity of the parents the highest part of the children are classified in the group of high risk. 
Conclusion: The caries risk assessment and the cooperativeness of the children is really important for the choice of treatment method, restoration materials and prophylaxis of the dental caries.

Keywords: caries risk assessment, cooperativeness, 5-7-year-old children.

\section{Introduction}

The contemporary knowledge about the dental caries, as a multifactor disease, left without control measures, needs special prophylactic programs for its prophylaxis $(1,2)$. For its control it is necessary a complex approach which includes caries risk assessment, recommendations for healthy life style and professional dental care by the general practitioners $(3,4)$. The cooperativeness of the most part of the little patients can not provide the necessary conditions for the tooth preparation and restoration of the affected teeth. In these cases, the filling materials with strict application protocol are not the best choice for restoration (5). The better choice of material would be the one which is moisture tolerant with relatively high durability (6). Unfortunately not all the children are capable of high cooperativeness during the treatment under local anesthesia (7). The reason may be the child's age or physical and psychic disturbances, which require sedation or even general anesthesia for high quality dental treatment to be provided (8-11). During this type of treatment it is obligatory the use of restoration materials (such as compomers, PMCs etc.) which will provide high durability in long term and which will decrease the chances of recidives in near future $(12,13)$.

\section{Aim}

Assessment of the caries risk and the cooperativeness of 5-7-year-old children.

\section{Materials and methods}

Object of observation are 100 5-7-year-old children, examined in the Medical Dental Center of Medical University - Varna in the period of 2015-2017. The assessment of the cooperativeness was done by the dentist using the 4-degree scale of Frankel. Information for the childs behavior was received also from the parent who filled anonymous questionnaire.

The caries risk assessment was made on the information from the clinical examination, dental status (dmft index), number of active caries lesions and anamnesis. For the purpose of the caries risk assessment the American Academy of Pediatric Dentistry (AAPD) tool was used. According to this tool the following criteria was examined: frequency of carbohydrate intakes, level of the oral hygiene, caries activity in parents, social status, protective factor - fluoride prophylaxis

\section{Results}

At the beginning of every child's treatment the dentist assessed the cooperativeness of each child using the Frankel scale as highly positive, positive, negative or highly negative. The dentist received information about 
the child's behavior also from the parents (questionnaire for parents). The children's behavior was determined as slightly negative at $32 \%$ of them, at $44 \%$ it is positive and highly positive behavior have $24 \%$ of the children. There was no statistically significant difference in the received data for the three groups of children. $(p>0,05)$.

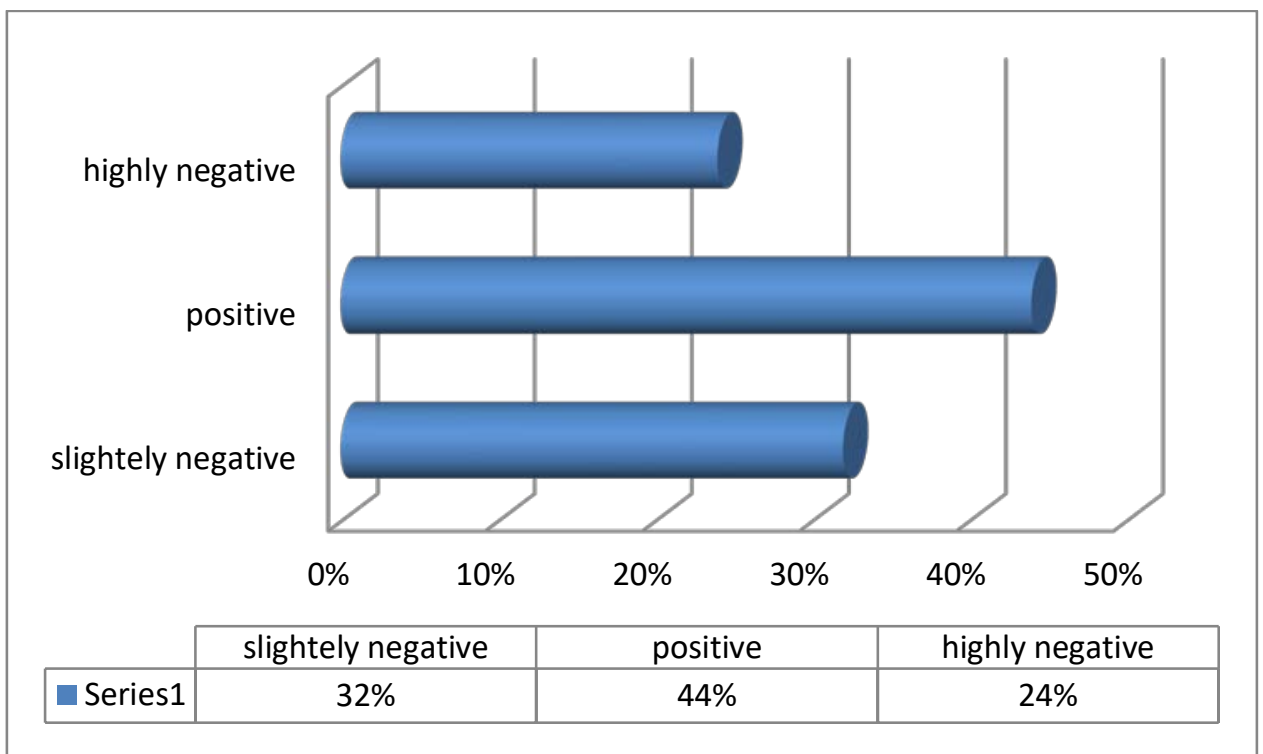

Fig.1 Children's behavior assessed by the dentist according to Frankel scale

The parents assessed their children as negative before the dental treatment at the $35 \%$ of the cases and as positive in $47 \%$. The parents assessed their children's behavior in $18 \%$ of the cases as a highly positive. There was no statistically significant difference in the behavior assessment by the dentist and the parents $(p>0,05)$.

\begin{tabular}{|c|c|c|c|c|c|c|}
\cline { 2 - 6 } \multicolumn{1}{c|}{} & \multicolumn{2}{c|}{ Negative } & \multicolumn{2}{c|}{ Positive } & \multicolumn{2}{c|}{ Highly positive } \\
\hline Dentist & $\mathrm{n}=16$ & $32 \%$ & $\mathrm{n}=22$ & $44 \%$ & $\mathrm{n}=12$ & $24 \%$ \\
\hline Parents & $\mathrm{n}=17$ & $35 \%$ & $\mathrm{n}=23$ & $47 \%$ & $\mathrm{n}=9$ & $18 \%$ \\
\hline & $\mathbf{x}^{2}=\mathbf{1 . 0 9 0}$ df $=\mathbf{2} \quad \mathbf{P}=\mathbf{0 . 5 7 9 7}$ & & \\
\hline
\end{tabular}

Table 1. Distribution of the children according to their behavior, assessed by the dentist and the parents.

The caries risk assessment is an obligatory element of every child's dental examination. Table 2 presents the distribution of the examined children in the current study in three groups according to caries risk assessment tool - low, medium and high risk. 
IS S U E 1, 2019

\begin{tabular}{|c|c|c|c|}
\hline & Low risk (1) & Medium risk (2) & High risk (3) \\
\hline$d m f t / d m f(T+t)$ & $7 \%$ & $10 \%$ & $83 \%$ \\
\hline Oral hygiene & $18 \%$ & $58 \%$ & $24 \%$ \\
\hline Carbohydrate diet & $18 \%$ & $34 \%$ & $48 \%$ \\
\hline Caries activity & $14 \%$ & $41 \%$ & $42 \%$ \\
\hline $\begin{array}{l}\text { Caries activity in } \\
\text { parents }\end{array}$ & $28 \%$ & $15 \%$ & $57 \%$ \\
\hline Social status & $5 \%$ & $59 \%$ & $36 \%$ \\
\hline Control visitations & $10 \%$ & $66 \%$ & $28 \%$ \\
\hline $\begin{array}{l}\text { Fluoride } \\
\text { prophylaxis }\end{array}$ & $34 \%$ & $14 \%$ & $52 \%$ \\
\hline & $\begin{array}{l}T_{1,3}=4 \\
T_{1,2}= \\
T_{2,3}=1\end{array}$ & $\begin{array}{l}X^{2}=44.295 \\
X^{2}=28.688 \\
2^{2}=42.316\end{array}$ & $\begin{array}{l}P<0.05 \\
P<0.05 \\
P>0.05\end{array}$ \\
\hline
\end{tabular}

Table 2. Percentage distribution of the children regarding the risk and protective factors in the caries risk assessment.

Differences in the percentage ratio between risk factors and protective factors in the different groups was observed. From the clinical data, $d m f(T+t)$ and the caries activity have the most important role which put the children in the high risk group. Regarding the oral hygiene 58\% of the children were put in the group of medium risk. Regarding to the risk biologic factors carbohydrate diet and caries activity of the parents the most of the children are in the group of high risk. 59\% of the children with low social status are in the group of medium risk. Regarding to protective factors in the group of high risk it was observed that more than half of the children did not receive any fluoride prophylaxis. The control visitations in $28 \%$ of the children with high risk are only when it is necessary. At $66 \%$ of them the control visitations are once per year, which puts them in the group of medium risk and barely $10 \%$ of the examined children (low risk) the visitations in the dental office are twice per year.

\section{Discussion}

According to a study in Bulgaria the parents had good assessment for their children's fear of dental treatment (14).

Ilieva (15) reports that 22,26\% of the children in Bulgaria on age of 4 to 12 years have necessity of behavior modeling before the dental treatment. Our received data supports this statement. The data received by Andreeva (16) for the children with premature tooth loss show that more than half of them have fear of dental treatment. She examined and assessed the behavior of the children using Frankel scale and reported that most of the children are slightly negative (17). 
In Bulgaria the status of the caries distribution in children with disabilities is very slightly studied. Doychinova (18) for the first time assessed the caries risk in children with disabilities in Bulgaria (19). It is established that the most significant risk factors in children with disabilities are the caries intensity, the bad oral hygiene and the carbohydrate intake compared to healthy control group. The studies show higher values of DMF index compared to the healthy siblings of the control group $(20,21)$. The received data from our study regarding the caries distribution and the frequency of the carbohydrate intake are close to the reported by Doychinova in healthy children. Differences in the results were established regarding the caries activity, the oral hygiene, fluoride prophylaxis, the caries activity in parents, social status and control visitations in the dental office (18). Andreeva (16) also received the frequency of the carbohydrate intakes for 30 children with premature loss of primary teeth and reported that $50 \%$ of them have high carbohydrate intake. The received data in our study are close to her results. Andreeva examined the social status of the households. The results from her survey show that over $70 \%$ of them have average money income. Regarding the regular control visitations the data established in our study is different (22). Her results show that $34 \%$ of the children have control visitations twice per year and for the biggest part of the examined children - one control visitation per year.

\section{Conclusion}

The caries risk assessment and the cooperativeness of the children is really important for the choice of treatment method, restoration materials and prophylaxis of the dental caries.

\section{References}

1. Andreeva R, Dental status assessment of children treated under general anesthesia, Scripta Scientifica Medicinae Dentalis. 2018, 2(1):49-52.

2. Peneva M., Rashkova M., Doichinova L. Age distribution of caries lesions in children,s permanent teeth - a basis for the choice of a therapeutic solution. J of IMAB 2007; 13(2):58-60.

3. Andreeva R, Karayasheva D. Significance of the D4MF $(T+t)$ index for the children with prematurely extracted teeth Scripta Scientifica Medicinae Dentalis, vol. 2, No 1, 2016, pp. 54-57

4. Rashkova M, Peneva M, Doychinova L. Study of the risk factors for the development of dental caries and creation of a system for evaluation of the risk of caries in children OHDMBSC 2009; 8 (3); 311. Available at: http://oralhealth.ro/volumes/.

5. Rahimtoola S, Van Amerongen E, Maher R, Groen H. Pain related to different ways of minimal intervention in the treatment of small caries lesions. J Dent Child 2000;67:123-127.

6. Nicholson JW, Croll TP. Glass-ionomer cements in restorative dentistry. Quintessence Int. 1997;28:705-714.

7. Andreeva R, Arnautska $H$, Georgiev T. Significance of the D4MF $(T+t)$ index for the children with prematurely extracted teeth. Scripta Scientifica Salutis Publicae, vol. 2, No. 1, 2016, 60-62

8. Андреева Р., Обща анестезия и седация в детската дентална медицина - определение, цел, предимства и недостатъци, Варненски медицински форум, т. 7, 2018, брой 2, 112-116

9. Андреева Р., Разпространение и анестезиологични аспекти на денталното лечение на деца чрез седация и под обща упойка, Варненски медицински форум, т. 7, 2018, брой 2, 117-121.

10. Andreeva R, Indications for dental treatment under general anesthesia, Scripta Scientifica Medica, 2018;50(3): 26-29. 
11. Holmes RD, Girdler NM. A study to assess the validity of clinical judgement in determining paediatric dental anxiety and related outcomes of management. Int J Paediatr Dent. 2005;15:169-176.

12. Andreeva R.,Assessment of different types of materials of children treated under general anesthesia, MedInform. 2018; 2:858-862

13. Cameron A, Widmer R : Handbook of Pediatric Dentistry. Germany: Mosby. 2013; (4): 93-102.

14. Shindova M., Belcheva A., Mateva N. Factors in dental environment related to development of child dental fear and parent-child agreement of its evaluation. Science and Technologies 2014, 4(1); 9195.

15. Илиева Е. Детето - пациент на стоматолога. Пловдив 2000, 17-21.

16. Андреева. Р., Преждевременна загуба на временни зъби при деца с ранно смесено съзъбие. Профилактика с местопазители, Дисертационен труд, Варна 2016; стр 60-68.

17. Andreeva R., Georgieva M., Dimitrov E., Belcheva A. Connection between the childs behavior in the dental office and premature tooth extraction. Medinform 2016 (1), 409-413.

18. Дойчинова Л., Дисертация за придобиване на ОНС „доктор“ на тема „Специални орални грижи за деца с увреждания" - София, 2014.

19. Doichinova L. Risk assessment for the development of caries in visually impaired children in Sofia city, Bulgaria. IJSR February 2015; 4(2): 1108-1111.

20. Дойчинова Л., М. Пенева Дентално здраве при деца със зрителни дефекти. Проблеми на денталната медицина, XXXVI/2010, 1-ва част: 41-48.

21. Doichinova L. Peneva M. Prevalence of dental caries in hearing impaired children than 5 to 12 years old in Sofia. IJSR January 2015; 4(1): 1088-1091.

22. Andreewa R. Assessment of fluoride prophylaxis in children with mixed dentition in connection with the risk of early tooth loss, Scripta Scientifica Salutis Publicae, vol. 2, No. 2, 2016, 13-15

\section{Corresponding author:}

Milena Todorova Georgieva-Dimitrova,

Faculty of Dental Medicine,

Medical University Varna,

84 Tzar Osvoboditel Str.,

9002 Varna, Bulgaria,

Tel.: 0883424786,

email: dr.milena.georgieva89@gmail.com 